practitioners, should enable rational use of antivirals. Positive predictive value of influenza diagnosis may increase up to $70 \%-80 \%$ during times when influenza is known to be circulating and duly alerted general practitioners use cough and fever as the most predictive symptoms. ${ }^{12 \mathrm{w} 1}$ Within half an hour of receiving a sample, rapid testing (immunoassays or viral neuraminidase detection) could be used two to four hours later by antibody staining tests and eventually by viral culture. $^{12 \mathrm{w1} \text { w2 }}$ Secondly, cumulative knowledge of which agents circulated during the season would enable apportioning a share of influenza-like illness burden to each, the formulation of better predictions of the effects of vaccines and antivirals, and would help clarify decision making rules. Emerging threats such as those from coronavirus and metapneumovirus would also be quantified and help focus efforts on production of new vaccines and antivirals." ${ }^{\mathrm{w} 3}$

In the absence of such knowledge, it is difficult to see how routine, explicit, and rational use of what we have can be made.

\section{Tom Jefferson coordinator}

Cochrane Vaccines Field, Via Adige 28a, 00061 Anguillara Sabazia, Rome, Italy (Toj1@aol.com)

Competing interests: TJ has received fees for consultancies, research, or speaking engagements from GlaxoSmithKline, Roche, and Sanofi-Synthelabo.
1 Nicholson KG, Kent J, Hammersley V, Cancio E. Acute viral infections of upper respiratory tract in elderly people living in the community: comparative, prospective, population based study of disease burden. BMJ 1997;315:1060-4.

2 Makela MJ, Puhakka T, Ruuskanen O, Leinonen M, Saikku P, Kimpimaki $\mathrm{M}$, et al. Viruses and bacteria in the aetiology of the common cold.J Clin Microbiol 1998; 36:539-42.

3 Zambon MC, Stockton JD, Clewley JC, Zambon MC, Fleming DM. Contribution of influenza and respiratory syncytial virus to community cases of influenza-like illness: an observational study. Laty cases of influenza-like ilness: an observational study, Lancet 2001;358:1410-6.

4 Demicheli V, Rivetti D, Deeks JJ, Jefferson TO. Vaccines for preventing influenza in healthy adults. Cochrane Database Syst Reo 2004;3: CD001269

5 Wilkinson P, Pattenden S, Armstrong B, Fletcher A, Kovats R, Mangtani P, et al. Vulnerability to winter mortality in elderly people in Britain: population based study. BMJ 2004;329:647-51.

6 Jefferson T, Deeks JJ, Demicheli V, Rivetti D, Rudin M. Amantadine and rimantadine for preventing and treating influenza $\mathrm{A}$ in adults. Cochrane Database Syst Rev 2004;3:CD001169.

7 Cooper NJ, Sutton AJ, Abrams KR, Wailoo A, Turner D, Nicholson KG, et al. Effectiveness of neuraminidase inhibitors in treatment and prevention of influenza A and B: systematic review and meta-analyses of randomised controlled trials. BMJ 2003;326:1235-40.

8 Jefferson T, Demicheli V, Deeks JJ, Rivetti D. Neuraminidase inhibitors for preventing and treating influenza in healthy adults. Cochrane Database Syst Rev 2000;(2):CD001265.

9 Harling R, Hayward A, Watson JM. Implications of the incidence of influenza-like illness in nursing homes for influenza chemoprophylaxis: descriptive study. BMJ 2004;329:663-4.

10 Matheson NJ, Symmonds-Abrahams M, Sheikh A, Shepperd S, Harnden Matheson NJ, Symmonds-Abrahams M, Sheikh A, Shepperd S, Harnden
A. Neuraminidase inhibitors for preventing and treating influenza in children. Cochrane Database Syst Rev 2003;(3):CD002744.

11 Kiso M, Mitamura K, Sakai-Tagawa Y, Shiraishi K, Kawakami C, Kimura $\mathrm{K}$, et al. Resistant influenza A viruses in children treated with oseltamivir: descriptive study. Lancet 2004;364:759-65.

12 Zambon M, Hays J, Webster A, Newman R, Keene O. Diagnosis of influenza in the community: relationship of clinical diagnosis to confirmed virological, serologic, or motons of tion of inflenza Arch Jntern Med 2001;161:2116-22.

\title{
New mental health legislation
}

\author{
Scottish legislation, based on "care and treatment," has lessons to offer
}

$\mathrm{R}$ eform of mental health legislation in England and Wales has caused widespread concern. ${ }^{12}$ Initial recommendations, from an expert committee for progressive and ethical reform, mutated into an initial draft bill uniting all interested organisations in opposition. ${ }^{3}$ Despite suggestions that the bill would be shelved, ${ }^{4}$ a revised draft bill, apparently addressing the concerns expressed, has been published. Meanwhile Scotland has new legislation-the Mental Health (Care and Treatment) (Scotland) Act 2003. Several organisations have pointed towards Scottish reform as an example of how things should be approached south of the border. ${ }^{3}$

The Mental Health (Scotland) Act 1984 is similar to the Mental Health Act 1983, both tracing origins to the Percy Report of $1957 .{ }^{5}$ In Scotland, in parallel with review in England and Wales, well received recommendations from an expert committee led to a positive response from government. ${ }^{6-8}$ The new act received royal assent in April 2003 and starts in April 2005. Major differences in Scotland are that the act adheres to recommendations from the expert committee and the process has not been hijacked by a government department more concerned with locking up dangerous offenders than with the care of people with mental health problems. Another committee considered offenders who pose a high risk to others; $;{ }^{90}$ its proposals were appropriately placed within the criminal justice system, resulting in specific criminal legislation.

The ethical basis for mental health legislation has developed from paternalism, emphasising dangerous- ness and humane care, towards autonomy, emphasising individual rights and capacity. Autonomy features prominently in the new act (box on bmj.com). It starts with guiding principles with no reference to risk, dangerousness, or public safety among these. The categories of mental disorder are modernised and exclusions are retained. To compel treatment, patients must be treatable, some risk to self or others must exist, and their ability to make decisions about treatment should be clinically significantly impaired because of their mental disorder. The last point introduces incapacity into compulsion criteria, although the term is absent because of its central place in specific incapacity legislation. ${ }^{11}$

Emergency and short term detentions in hospital remain, but longer term compulsory treatment orders will be available in hospital or in the community. Community orders will allow compulsory medication, with non-compliance leading to potential hospital detention. The introduction of the Mental Health Tribunal for Scotland marks a major change in the legal review process. Extra safeguards and supports should be provided by advocacy services, the recognition of advance statements, an extended role for the Mental Welfare Commission for Scotland, and the introduction of named people.

A broad range of orders will remain available for offenders with mental disorders, but the incapacity cri- 
terion will not apply-an understandable, but perhaps ill thought through, discriminatory measure. Procedures for the most worrying offender patients are included but contained within sections relating to restriction orders and not pervading the act. Public safety will continue to trump all other issues in decisions on discharging restricted patients and comprehensive assessment in hospital will be necessary before such disposals are made. ${ }^{12}$

In a previous editorial Birmingham summarised the main proposals in the initial draft bill for England and Wales. ${ }^{2}$ Superficially this draft bill and the Scottish act look similar, but important differences make most concerns about that bill inapplicable: to whom the act applies is strictly defined, with exclusion criteria; no over-emphasis on risk to others; inclusion of capacity; inclusion of ethically sound principles; no loss of discretion for services in applying procedures; comprehensive legislation on incapacity already in place; no compulsory treatment in prison; and genuinely responsive consultation by government. Clinicians and other stakeholders have been closely involved in the review and implementation processes in Scotland. The new draft bill for England and Wales only really addresses the concern about prison treatment; the other concerns remain valid, marking clear and persisting differences between legislative proposals in the two jurisdictions.

In Scotland concern remains about resources, bureaucracy, implementation, and training. Currently patients rarely contest detention, but new tribunal hearings will occur frequently, requiring personnel and infrastructure, and potentially disrupting clinical care. Tribunals will also consider appeals against being held in excessive security. This measure must start in May 2006 despite the likelihood that beds will be insufficient to cater for patients who no longer require care in a high security hospital.

The long term impact of complex legislation that allows much room for discretion is difficult to predict. The act on paper may not match the act in practice, so day to day reality may be different from the intention behind the policy. Funding for research on the opera- tion of the new act is promised. Scotland will have ethically sound modern legislation, with principles supported by most stakeholders. In the United States, cycles of reform show that impact is less dramatic than predicted by optimists or pessimists. ${ }^{13}$ New legislation reflects, rather than changes, social, clinical, or political aspirations. In Scotland, unlike England and Wales, considerable harmony has existed between these. However, new legislation does not in itself provide improvements in clinical care or resources.

Rajan Darjee lecturer in forensic psychiatry

(rajan.darjee@ed.ac.uk)

John Crichton consultant forensic psychiatrist

(John.Crichton@lpct.scot.nhs.uk)

Division of Psychiatry, Kennedy Tower, Royal Edinburgh Hospital, Edinburgh EH10 5HF

Competing interests: RD was seconded to the Scottish Executive mental health law team. JC chaired the working group of the advisory board of the Forensic Mental Health Services Managed Care Network, on levels of security.

1 Szmukler G. A new mental health (and public protection) act. BMJ 2001;322:2-3.

Birmingham L. Detaining dangerous people with mental disorders. BMJ 2002;325:2-3.

The Mental Health Foundation. Mental health bill. Response by the mental health foundation and foundation for people with learning disabilities. London: Mental Health Foundation, 2002 wwwmentalhealth orguk/html content/response mhb engwales_0902.pdf (accessed 3 Jun 2004).

4 Batty D. Mental health bill future in doubt. Guardian 2004 June 15 Batty D. Mental health bill future in doubt. Guardic
http://society.guardian.co.uk/mentalhealth/story/ http://society.guardian.co.uk/mentalhealth/story/

5 Royal Commission on the Law relating to Mental Illness and Mental Deficiency Royal Commission on the Law relating to Mental
1954-7. Cmnd 169. London: HMSO, 1957.

1954-7. Cmnd 169. London: HMSO, 1957.
Scottish Executive. New directions. Report of the review of the Mental Health (Scotland) Act 1984. Edinburgh: Scottish Executive, 2001.

7 Scottish Executive Renewing mental health law. Policy statement. Edinburgh: Scottish Executive, 2001

8 Darjee R. The reports of the Millan and MacLean committees: new proposals for mental health legislation and for high risk offenders in Scotland.J Forens Psychiatry 2003;14:7-25.

9 Scottish Executive. Report of the committee on serious violent and sexual Scottish Executive. Report of the committee on
offenders. Edinburgh: Scottish Executive, 2000.

10 Darjee R, Crichton J. The MacLean committee: Scotland's answer to the Darjee R, Crichton J. The MacLean committee: Scotland's answer to the
dangerous people with severe personality disorder proposals? Psychiatr Bull 2002;26:6-8.

11 Ward A. Adult incapacity. Edinburgh: W Green, 2003.

12 Crichton J, Darjee R, McCall Smith A, Chiswick D. Mental Health (Public Safety and Appeals) (Scotland) Act 1999: detention of untreatable patients with psychopathic disorder. J Forens Psychiatry 2001;12:647-61.

13 Appelbaum PS. Almost a revolution. Mental health law and the limits of change. New York: Oxford University Press, 1994.

\section{Surgery for carotid artery stenosis}

\section{We need to screen populations to detect stenosis and treat it}

$\mathrm{T}$ The US Veterans' Administration study followed by the asymptomatic carotid artery stenosis study (ACAS) and now the asymptomatic carotid stenosis trial (ACST) have all affirmed that elective endarterectomy for patients carefully selected by neurologists and operated on by skilled surgeons can

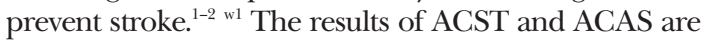
almost identical, with $5.4 \%$ absolute risk reduction for stroke in ACST compared with 5.9\% for ACAS. The surgical advantage persists despite multimodal medical management with statins, platelet antiaggregants, and stringent control of risk factors. Moreover, nearly $20 \%$ of asymptomatic patients randomised to the medical management arm of ACST developed symtoms during the domised trials all show that if medical management has failed elective endarterectomy performed by skilled surgeons is a worthwhile additional option for management of presymptomatic carotid stenosis that exceeds $60 \%$, for otherwise healthy men and women regardless of their age, if medical management has failed.

On the other hand, using transient ischaemic attack or minor stroke as the marker for surgery entails a complication rate of about $6 \%$. To be added to this figure is the additional hazard of contrast arteriography (about $1 \%$ ). Advising patients with carotid stenosis to

Additional references w1-w6 are on bmi.com 